\title{
光表面実装技術向け光ピンの光導波路への結合
}

\author{
村田 佳一 *, 渡邊 則利*, 尾山 雄介*, 三上 修*, 内田 禎二**
}

\section{Coupling of Optical Pin to Optical Waveguide for Optical Surface Mount Technology}

\author{
Yoshikazu MURATA*, Noritoshi WATANABE*, Yusuke OYAMA*, Osamu MIKAMI* and Teiji UCHIDA**
}

\footnotetext{
* 東海大学電子情報学部（～２59-1292＼cjkstart神奈川県平塚市北金目 1117）

** 東海大学総合科学研究所（广 259-1292 神奈川県平塚市北金目 1117）

* School of Information Technology and Electronics, Tokai University (1117 Kitakaname, Hiratsuka-shi, Kanagawa 259-1292)

** Research Institute of Science \& Technology, Tokai University (1117 Kitakaname, Hiratsuka-shi, Kanagawa 259-1292)
}

\begin{abstract}
概要 光インタコネクション実現のために, 電気プリント配線板と設計・評価・実装プロセスを共有できる新たな光エレ クトロニクス実装技術として，光表面実装技術が提案されている。これまで，基板内の光配線と表面実装した光デバイスとの 光結合を行うために, 端面を 45 度加工した光ファイバ（光ピン）の基本特性を検討してきた。本報告では実際に導波路上に 作成したホールへ光ピンを挿入し, 結合効率や位置ずれ・回転トレランス特性などを測定した。光線追跡法を用いた光結合 シミュレーションの検討も行った。また光ピンの 45 度ミラー面における「透過光」を軽減するために, ミラー面へ反射率の高 い金属膜を蒸着し，結合効率の向上とマッチングオイル使用による効果を検討した。
\end{abstract}

\begin{abstract}
We have proposed an application of an optical pin having an end of a 45-dgree micro mirror to coupling between optical wirings and optical devices in Optical Surface Mounting Technology. In this paper, experimental studies on optical characteristics of the optical pin having an end coated with a metallic film were reported. Then, the fabrication process of a through-hole on a polymeric waveguide substrate by a laser ablation technique was described. Next an optical pin was actually inserted into the through-hole and the coupling efficiency was studied. Theoretical studies on optical coupling characteristics were also performed using a ray tracing simulation. It was shown that the optical pin has high feasibility by using both metallic coated optical pin and index matching oil.
\end{abstract}

Key Words: Optical Surface Mount Technology, Optical Pin, Optical Waveguide, Coupling Efficiency, Ray Trace Simulation, Optical Packaging

\section{1. 緒 論}

ここ数年で，xDSLやFTTH，高速無線LANなど，さま ざまな形で広帯域な通信サービスが実現し, 通信の多様化, 広帯域化が社会に与える影響は日々大きくなっている。イ ンターネット人口は日本だけでも 6000 万人を優に超え, 2 人に 1 人は何らかの形でインターネットを利用している。 このようにインターネットの爆発的な普及に伴い, ネット ワークを流通する情報量は増大している。この膨大な情報 を円滑に伝送, 処理するためには, コンピュータ, 交換機 等の通信情報処理装置などの高性能電子計算機・装置に対 して処理能力の飛躍的向上が求められている。 $\mathrm{CPU}$ 等の電 子LSI の性能は着実に向上しているが, 信号の高速化に伴 うクロストーク, 電磁輻射, さらには電気配線による信号 伝送の帯域制限等の問題がシステム性能向上のボトルネッ クとなっている。この解決のため, 光信号のもつ高速, 低 損失, 無誘導等の特徴を生かし, 電気信号に代わって光信 号によってインタコネクションする「光インタコネクショ
ン」が期待されている。現在の光エレクトロニクス技術を 眺めると, 半導体レーザや光検出器といった個々のデバイ スの性能向上に関する研究開発面は着実に進歩してきた。 しかし, 配線上, 寸法上, 信号の伝わり方等でエレクトロ ニクス (電気) とは異なる「光の特殊性」のため, 集積化 や実装技術面で深刻な課題にぶつかっている。このため新 たな光エレクトロニクス実装技術が必要である。

この課題を解決する手段として, 光表面実装技術 ${ }^{1), 2)}$ (Optical Surface Mount Technology: 光 SMT) が提案されて いる。光SMTは, 電子回路の表面実装技術に対応するボー ドレベルでの新しい光実装技術である。光・電子表面実装 デバイス (OE-SMD: Opto-Electronic Surface Mount Device) と, 光導波路亡電気配線で構成された光電気配線板 $(\mathrm{OE}-$ PWB: Opto-Electronic Printed Wiring Board) を主要構成部品 とし, 光電気配線板に OE-SMD をマーカ, 嵌合孔を用いて マウントすることにより, 光結合される仕組みとなってい る。光導波路を伝搬する光之光電気配線板上部にマウント する OE-SMD が効率良く結合するためには, 光導波路を伝 
搬する光が基板方向に対し垂直に光路変換（90 度光路変 換）する構造が必要である。従来は, 光導波路端にダイヤ モンドブレードを用いて 45 度ミラーを作製し， 90 度光路変 換構造を形成する方法が一般的であった。しかし，ミラー 作製プロセス上の問題として, 光電気配線板の任意の場所 に局所的に 45 度ミラーを形成することが困難であること， また近くに配置された光配線を断線する心配があった。

そこで新たに, 光電気配線板の所定の場所にあらかじめ ホールを加工し， 45 度マイクロミラーを有する光ピンを差 し込むことによって, 光SMTに不可欠な 90 度光路変換を 実現する方法が提案されている ${ }^{3), 4)}$ 。従来の電気配線板にお ける, リード挿入など局所的に電気信号を取り出すことが できることが可能な作製プロセスを, 光実装技術にも適用 したものである。光電気配線板の所定の位置にホールを加 工し，そこに 45 度ミラー面を有する光ピンを挿入し OE$\mathrm{SMD}$ をマウントする。または, あらかじめ光ピンに OESMD を装着しておき, それを挿入しエポキシなど光学接着 剂で固定することで 90 度光路変換を実現させる方法であ る。光ピンはダイヤモンドブレードを用いて端面を 45 度に 加工し, 90 度光路変換を行うためのマイクロミラーを作製 した光ファイバである ${ }^{1)}$ 。Fig. 1 に面発光レーザ (VCSEL: Vertical Cavity Surface Emitting Laser) Array, PD-Array, Guide Pin を搭載したOE-SMDの構成図を示す。Fig. 2 に, 光ピンを用いた光 SMT 構成図を示す。

これまで, 光ピンと光導波路との結合特性について, シ ミュレーションおよび測定にて検討を行い, 光ピンを用い た 90 度光路変換が可能であることを確認した。本研究で は, 実際に光導波路へホールを作製し, 光ピンをホールに 挿入し光導波路と結合させ, 光ピンと光導波路との結合特 性をシミュレーションと測定により検討を行った。また, 光ピンと光導波路の光結合効率を改善するために, ミラー 面へメタルコーティングを施した光ピンを作製し, あわせ て検討を行った。

\section{2. 光導波路上へのホール作製法}

光電気配線板に要求される条件として, 高性能な光導波 路亡電気回路が同一基板に作製可能で, 数十 $\mathrm{cm}$ 程度の大 型基板が経済的に作製可能であることが求められる。光導 波路にはさまざまな材料があるが, 中でも高分子材料を用 いた光導波路は加工性に優れ, 大型基板が作製可能, また 安価で軽量である。これらの特徴を考慮すると高分子材料 を用いた光導波路が光電気配線板として適していると考え られる。そこで光配線に高分子光導波路を用いることを想 定し, 光ピンを挿入するためのホールを作製し検討を行っ た。

\section{1 加エプロセス}

測定に使用した高分子光導波路（コア：d-PMMA，ク ラッド：UVエポキシ樹脂）に光ピンを挿入するためのホー

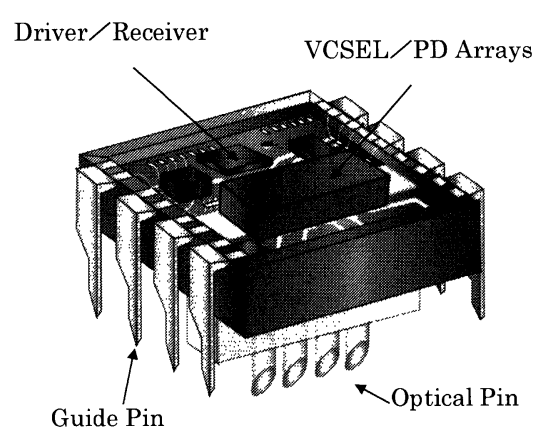

Fig. 1 Structure of proposed I/O package with optical pins

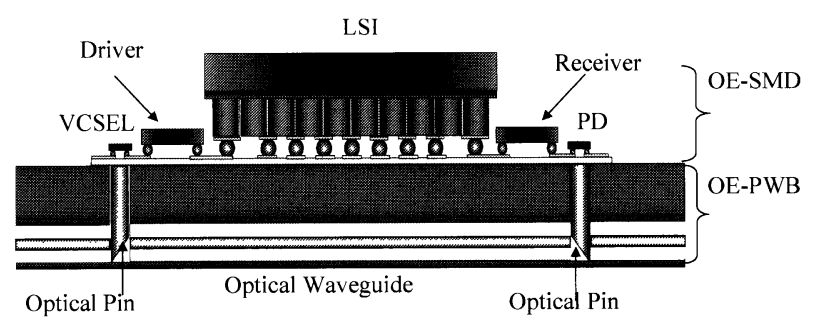

Fig. 2 Basic structure of optical surface mount technology with optical pins

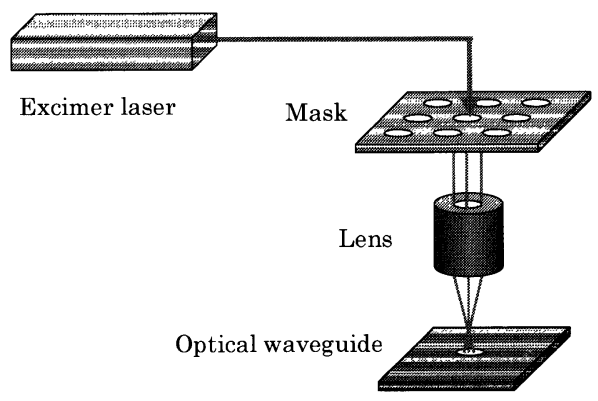

Fig. 3 Experimental setup for fabricating holes on polymeric waveguide

ルを，エキシマレーザを用いたレーザアブレーションによ り作製した。Fig. 3 に加工プロセスの概略図を示す。波長 $248 \mathrm{~nm}$, 出力 $15 \mathrm{~W}$, レーザ出力 $40 \mathrm{~mJ}$, 発振周波数 $600 \mathrm{pps}$, 照射時間 $5 \mathrm{sec}$ の条件でエキシマレーザから光をマ スク（径 $200 \mu \mathrm{m}$ ）を介し結合光学系を用いて光導波路に照 射した。

\section{2 ホールヘのクリーニング処理}

Fig. 4(a)に，実際に光導波路上に作製したホールのSEM 写真を示す。ホールは加工プロセス上テーパ角を有し, 上 面径 $220 \mu \mathrm{m}$, 底面径 $160 \mu \mathrm{m}$ と大きさが異なる。写真から 加工時に出たと思われる白いゴミのような付着物が確認で きる。そこで, このホールの加工面にクリーニング処理を 施した。クリーニングは酸素プラズマアッシングと, 過マ ンガン酸カリウムによるウエットエッチングの 2 通りを試 みた。Fig. 4(b)にクリーング処理を施したホールのSEM写 真を示す。

Fig. 4(b)の(A)酸素プラズマアッシングでは, Fig. 4(a)に見 


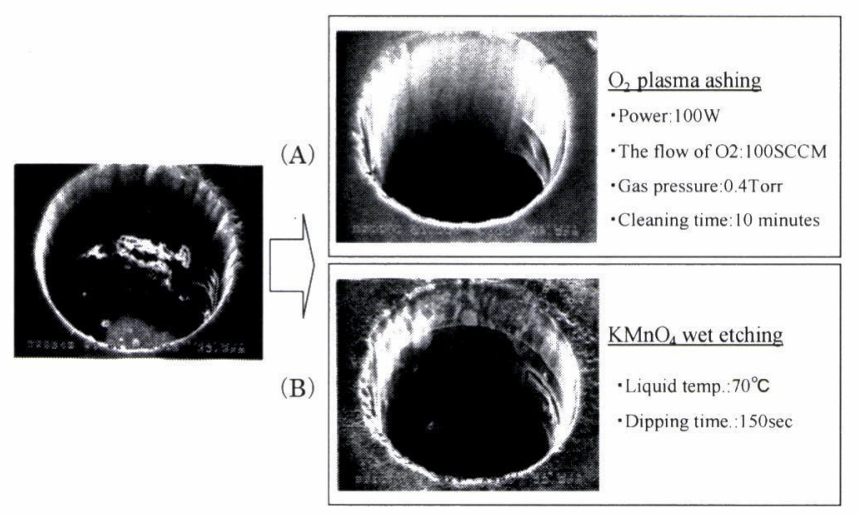

(a) after processing

(b) after cleaning
Fig. 4 SEM pictures of holes fabricated on a polymeric waveguide

られた付着物が除去されていることがわかる。また，導波 路のコアも SEM 像より確認できる。Fig. 4(b)の(B)過マンガ ン酸カリウムでは, 付着物は排除されているが, ホール一 面に膜のようなものが張り付いていることが確認できる。

\section{3 損失測定}

酸素プラズマアッシング, 過マンガン酸カリウムによる 処理どちらが光ピンを挿入するためのホール加工に適して いるかを検討するため，伝送損失の評価を行った。実験系 をFig. 5 に示す。前述と同様の材料の光導波路（長さ：約 $65 \mathrm{~mm}$, コア径：約 $40 \times 40 \mu \mathrm{m}$, 導波路ピッチ：約 $250 \mu \mathrm{m})$ の片端面にFig. 6 に示すような半円のホールを作製し， そ こに 2.2 説で述べた 2 通りのクリーニング処理を施したもの とクリーニング処理を施さないホールの 3 種について評価 を行った。ホールを作製していない端面から波長 $1.31 \mu \mathrm{m}$ の光をシングルモードファイバ (SMF: Single Mode Fiber) を 介して入射し, 導波路を伝搬して半円状のホールからの出

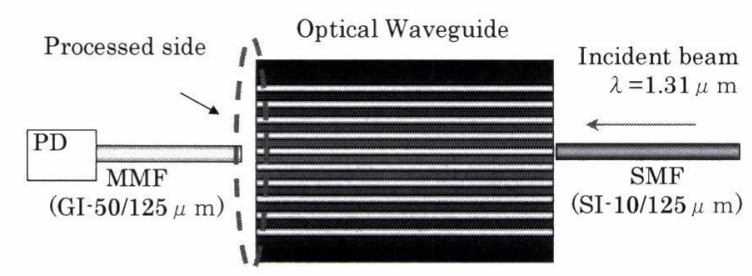

Fig. 5 Experimental setup of coupling between an optical fiber and a polymeric optical waveguide

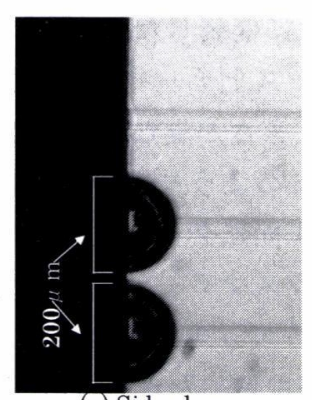

(a) Side shape

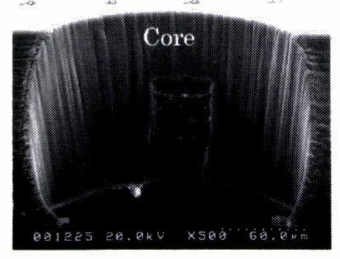

(b) Cross section
Fig. 6 SEM picture of holes fabricated on the side of polymeric waveguide
Table 1. Coupling loss obtained after the cleaning process

\begin{tabular}{l|c|c|c}
\hline & Non cleaning & $\mathrm{O}_{2}$ plasma & $\mathrm{KMnO}_{4}$ \\
\hline Coupling Loss & $7.5 \mathrm{~dB}$ & $4.2 \mathrm{~dB}$ & \\
\hline
\end{tabular}

射光をコア径 $50 \mu \mathrm{m}$ のマルチモードファイバ(GI-MMF)で受 光し伝送損失を測定した。入射光を基準光とした伝送損失 の測定結果を Table 1 に示す。過マンガン酸カリウム好理 では, ホールからの出射光を測定することができなかった。 これは，前にも述べたホール全体を覆っている薄い膜のよ うなものがコアを覆い, 光を遮っているためと考えられる。 また，クリーニング処理なしと酸素プラズマアッシング処 理を比較すると，クリーニング処理を施した方が，伝送効 率が約 $3 \mathrm{~dB}$ 向上している。したがって, 酸素プラズマアッ シングによるクリーニング処理を行ったホールを用いて, 結合実験を行った。

\section{3. メタルコーティングの効果}

\section{1 従来の光ピンの問題点}

光ピンの 45 度ミラー面では, 90 度光路変換を屈折率差 による全反射条件を用いて行っていた。しかし，45度ミ ラー面においては，すべての光が全反射条件を満たすわけ ではなく，一部の光が透過することが確認されている ${ }^{3), 4}$ 。 この透過光は結合効率を低下させる大きな原因となる他, 不要輻射光となり䛊作動や雑音の原因となる恐れがある。

Fig. 4 に示したスルーホールはホール端面には凹凸があ り, 理想的な円筒鏡面とは言えない。この場合, 光ピンを 挿入し矩形光導波路との光結合をするときに，この凹凸面 によって伝播光が散乱することが考えられる。円筒面の散 乱光は, スルーホール内のエアーギャプにマッチングオイ ルを注入することにより円筒面が平滑化され，ほぼ解決で きるが，45度ミラー面もマッチングオイルで埋められるた め全反射しなくなり，90 度光路変換ができなくなる。

そこでこの透過光の軽減とマッチングオイルの適用を目

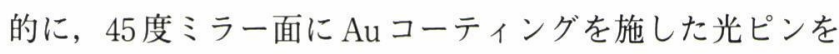
作製した。

\section{2 メタルコーティング光ピンの作製}

作製したメタルコーティング光ピンをFig. 7 に示す。使

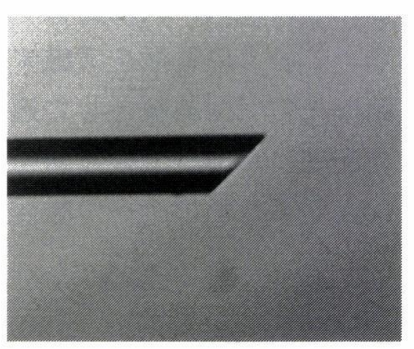

Fig. 7 Fabricated optical pin with Au coated micro mirror 
用した光ファイバは径 50/125 $\mu \mathrm{m}$ の(GI-MMF)で，その片端 面はFCコネクタを装着している。光ファイバ端面への 45 度面加工には, エポキシ等の光学接着剤で光ファイバを固 定し，45度面加工用の治具に沿ってブレードで切硡する方 法を用いた。そして 45 度ミラー面に $\mathrm{Au}$ を真空蒸着するこ とによってメタルコーティング光ピンを作製した。 $\mathrm{Au}$ 膜厚 は $0.3 \mu \mathrm{m}$ である。

次に，作製した光ピンの基本特性の検討を行った。FCコ ネクタ側から波長 $850 \mathrm{~nm}$ の LD 光を入射し，45度ミラ一面 で 90 度光路変換された光を $5 \mathrm{~mm}$ 径の PDで受光した。結 果, メタルコート処理をしていない光ピン（以降ノンコー ティング光ピン）は，入射した LD光に対する結合損失は 約 $1.0 \mathrm{~dB}$ であった。一方，メタルコーティング光ピンの結 合損失は $0.2 \mathrm{~dB}$ あり, $\mathrm{Au} コ$ コィングを施すことにより結 合損失 $0.8 \mathrm{~dB}$ の改善を確認した.

\section{4. 光ピンと光導波路との結合特性}

\section{1 結合シミュレーション}

光ピンと光導波路の結合特性を, 3 次元の光線追跡法を 用いてシミュレーションを行った。シミュレーションモデ ルを Fig. 8 に示す。コア径 $50 \mu \mathrm{m}$ の SI-MMFを光ピンとして 用い, 光導波路の構造パラメータはコア屈折率 : 1.489 , ク ラッド屈折率： 1.471 , コア径 $40 \times 40 \mu \mathrm{m}$ である。これらの 值は, 試験サンプルの光導波路と同じ仕様である。この光 導波路に上面径 $230 \mu \mathrm{m}$, 底面径 $140 \mu \mathrm{m}$ のホール形成した モデルとした。

ホール内で, 光ピンで 90 度光路変換して光を光導波路へ 入射する送信の場合と, 光導波路から光ピンで 90 度光路変 換して光ピン上部で受光する受信の場合についてシミュ レーションを行った。光ピンの 45 度ミラー面については, 光ピン（ガラス）と空気との屈折率差で全反射させるノン コーティング光ピンと, ミラー面にメタルコートを施し, 反射率を $100 \%$ と仮定したメタルコーティング光ピンをモ デルとした。メタルコーティングピンについては，マッチ ングオイルをホール内に充てんした場合は，屈折率を 1.50 としてシミュレーションを行った。

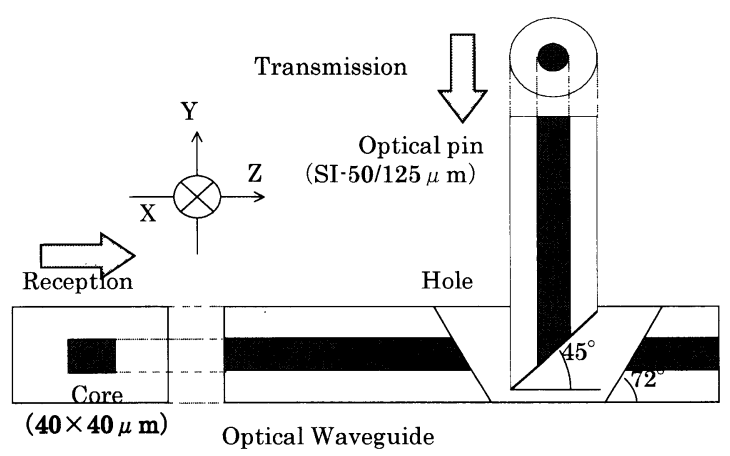

Fig. 8 Simulation model of coupling between an optical pin and an optical waveguide
シミュレーション結果を Fig. 9, 10 および Table 2 に示す。 なお，シミュレーション值は入射光を $100 \%$ としている。 Fig. 10(b)では光ピンのミラー面で反射した光線が光ピンの クラッドに漏れ，図が見にくくなるためクラッド内の光線 の記述を省略している。シミュレーションの結果, 結合損 失はノンコーティング光ピンで送信が約 $2.3 \mathrm{~dB}$, 受信が約 $10.8 \mathrm{~dB}$, メタルコーティング光ピンでは送信が $1.1 \mathrm{~dB}$, 受 信が約 $1.2 \mathrm{~dB}$ ，マッチングオイルを充てんした場合は送信 が $1.1 \mathrm{~dB}$, 受信が約 $0.8 \mathrm{~dB}$ であった。受信側で $0.4 \mathrm{~dB}$ の改 善がみられた。これはホール内の屈折率がほぼ同等となる ことで, 光導波路からの光束がホールのテーパ形状の影響 を受けなくなったためと考えられる。送信侧ではホールが 理想的な状態であるため変化がなかった。

4.2 トレランスシミュレーション

光ピンと光導波路との位置合わせトレランスについて, 光線追跡シミュレーションにより最大 $5 \%$ 結合損失が増加 するまでを許容度範囲として検討した。シミュレーション モデルはFig. 8 と同じである。なお，ホールの大きさが $140 \mu \mathrm{m} \phi$ (底面), 光ピンが $125 \mu \mathrm{m} \phi$ のため, 光ピンの位置 ずれは X, Z 軸についてはホール中心から最大 $\pm 7.5 \mu \mathrm{m}$ ま

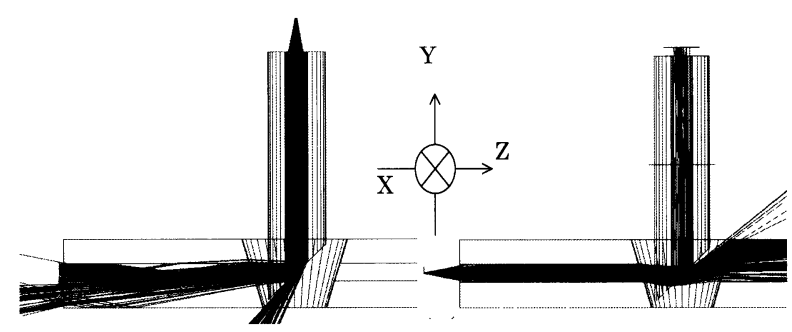

(a) Transmission

(b)Reception

Fig. 9 Calculated results of non-coating optical pin by ray trace simulation

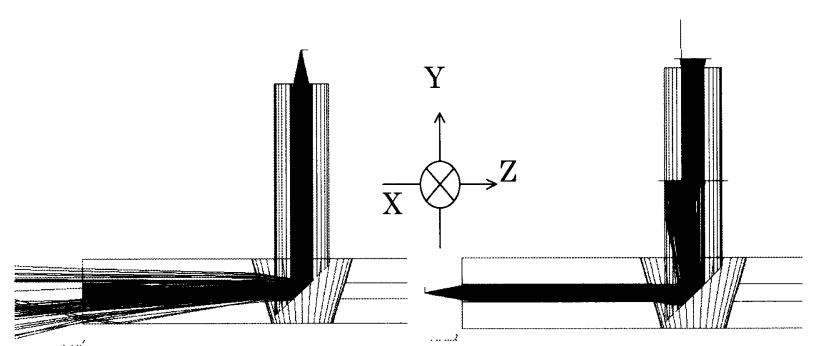

(a) Transmission

(b) Reception

Fig. 10 Calculated results of Au-coating optical pin by ray trace simulation

Table 2. Calculated coupling loss by ray trace simulation

\begin{tabular}{c|c|c}
\hline Optical Pin & Transmission & Reception \\
\hline Non-coating & $2.3 \mathrm{~dB}$ & $10.8 \mathrm{~dB}$ \\
\hline \multirow{2}{*}{ Metal-coating } & $1.1 \mathrm{~dB}$ & $1.2 \mathrm{~dB}$ \\
& $(1.1 \mathrm{~dB})$ & $(0.8 \mathrm{~dB})$
\end{tabular}

(): Coupling loss when the matching oil was filled into a through hole 
Table 3. Calculated tolerance by ray trace simulation

\begin{tabular}{l|c|c|c|c|c|c}
\hline & \multicolumn{3}{|c|}{ Non-coating } & \multicolumn{3}{c}{ Metal-coating } \\
\hline & $\mathrm{X}$ & $\mathrm{Y}$ & $\mathrm{Z}$ & $\mathrm{X}$ & $\mathrm{Y}$ & $\mathrm{Z}$ \\
\hline Transmission & $\pm 4 \mu \mathrm{m}$ & $\pm 8 \mu \mathrm{m}$ & $\pm 7 \mu \mathrm{m}$ & $\begin{array}{c} \pm 4 \mu \mathrm{m} \\
( \pm 7 \mu \mathrm{m})\end{array}$ & $\begin{array}{c} \pm 6.5 \mu \mathrm{m} \\
( \pm 6.5 \mu \mathrm{m})\end{array}$ & $\pm 7 \mu \mathrm{m}$ \\
$( \pm 7 \mu \mathrm{m})$
\end{tabular}

( ): Calculated tolerance when the matching oil was filled into a through hole

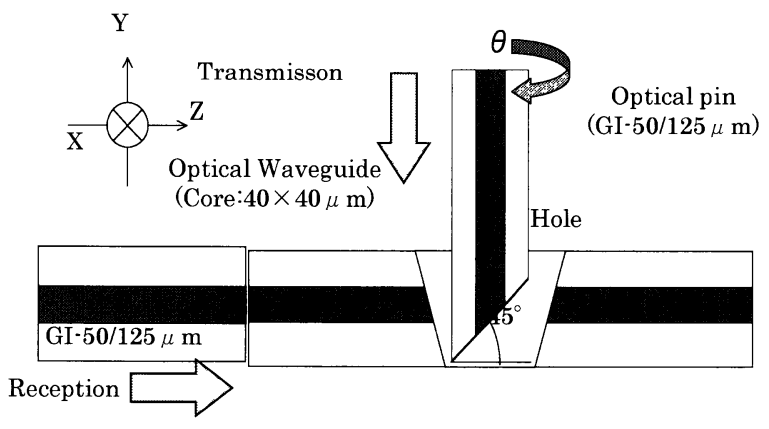

Fig. 11 Experimental setup of coupling between an optical pin and a polymeric optical waveguide

でとなる。シミュレーション結果をTable 3 に示す。ここで $\mathrm{X}, \mathrm{Z}$ 軸でのトレランスが $\pm 7 \mu \mathrm{m}$ という值は, 光ピン挿入 後にホール内で X, Z 軸方向に位置ずれが生じても結合効 率がほぼ5\%以内に収まることを示している。またこの表 より，Auコーティングを施すことによるトレランス幅拡大 の効果は見られないが，マッチングオイルを用いることで, 多少トレランス幅の拡大が見られた。

\section{3 光結合実験}

光ピンと光導波路の光結合について, Fig. 11 に示す実験 系で実測した。光ピンは, GI-MMF の端面に 45 度ミラー加 工したものとした。メタルコーティング光ピンは, ミラー 面に $\mathrm{Au}$ を蒸着させ作製した。光導波路の仕様は, コア屈 折率：1.489, クラッド屈折率： 1.471 , コア径 $40 \times 40 \mu \mathrm{m}$ で ある。マスク径は (1) $200 \mu \mathrm{m}$, (2) $175 \mu \mathrm{m}$ を作製した。なお， これらのマスクを用いてレーザアブレーションによるホー ルを作製した場合，テーパ形状のホールが形成され，それ ぞれ，(1) マスク径 $200 \mu \mathrm{m}$ ：上面ホール径 $220 \mu \mathrm{m}$, 底面 ホール径 $190 \mu \mathrm{m}(2)$ マスク径 $175 \mu \mathrm{m}$ ：上面ホール径 $190 \mu \mathrm{m}$, 底面ホール径 $175 \mu \mathrm{m}$ となる。このホールにノン コーティングとメタルコーティングの 2 種類の光ピンを挿 入して, 送受信の結合損失測定を行った。送信は光ピン上 部に発光素子を置くことを想定し, 光導波路からの光量を 測定した。受信はその逆の光ピン上部からの光量を測定し た。

測定サンプルは，各ホール径に対して 16 個のホールを設 け，おのおの 2 度測定し結合のばらつきを評価した。その 結果を Fig. 12, Fig. 13 に示す。なお，示した測定結果は光 導波路の伝搬損失, 矩形導波路との入射, 受光用のファイ

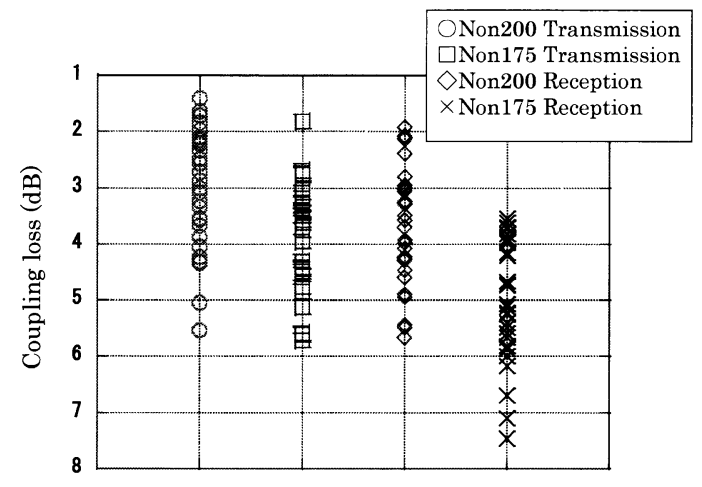

Fig. 12 Coupling loss obtained by a non-coating optical pin

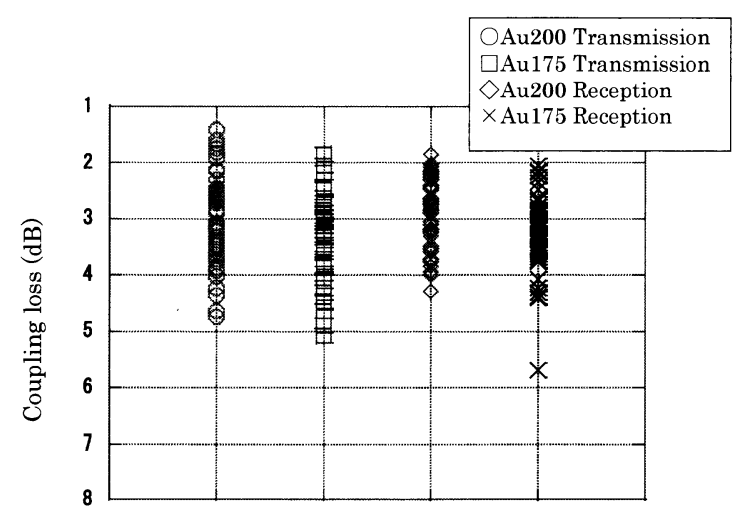

Fig. 13 Coupling loss obtained by an Au-coating optical pin

バとの結合損失を含めない值である。

ノンコーティング，メタルコーティング光ピンどちらむ， かなりのばらつきがあった。これは，各ホールの加工，ク リーニングの仕上がり具合が異なるためと考えられる。

これらの結果から以下のように整理できる。まず送受信 の比較をすると, メタルコーティング光ピンの場合は, 送 信と受信の結合効率の平均值が同等で, 変動幅も同じよう な分布をしている。一方，ノンコーティング光ピンの場合 は，送信に比べ受信の方が結合損失は大きくなっている。 またメタルコーティングにより，結合損失が $0.2 \sim 1.1 \mathrm{~dB}$ 程 度改善されている。特に，受信において改善効果が大きい。 これは，ホールのテーパ角および端面の凹凸による影響が 考えられる。すなわち，ノンコーティング光ピンにおいて， 受信の場合, 光導波路端面から入射された光は光導波路を 伝播していく。ホール内の光導波路の出射端が斜めになっ ており，少し下方に角度を持って反射する。これが光ピン に入射する。出射端面に凹凸があると, 出射する光は散乱 し, さらに放射角の分散の大きな光束となり, 光ピンのミ ラー面に達したとき全反射条件を満たさず透過してしまう 光の割合が増える。これがノンコーティング光ピンの受信 の場合において, 結合効率が低い原因と考えている。メ夕 ルコーティング光ピンの場合は全反射条件を満たさない光 でもメタルによって反射するので影響は少ない。この様子 
は, Fig. 10 のミュレーション結果からも確認できる。

マスク径 $200 \mu \mathrm{m}$ と $175 \mu \mathrm{m}$ で作製したホールについて比 較をする。まず結合効率の面から考える。Fig. 13 に示すよ うに Auコーティングを施すことで全体的な結合効率の分 布はおおむね同等である。最大結合効率をみるとマスク径 $200 \mu \mathrm{m}$ の送信側が $1.5 \mathrm{~dB}$ 程度と良好な值を得ており, その 他む大体 $2.0 \mathrm{~dB}$ 程度の值であった。このことからマスク径 による結合効率の影響は少ないと考えられる。結合効率の ばらつきはホール内壁の状態による影響と推測される。実 装面から検討すると, マスク径 $200 \mu \mathrm{m}$ の場合はホールが大 きいため光ピンが挿入しやすいが, 挿入後に位置調整が必 要になると考えられる。一方, マスク径 $175 \mu \mathrm{m}$ の場合では $200 \mu \mathrm{m}$ に比べ挿入しにくいが, 挿入後の大きな位置調整が 不要になるだろうと思われる。

\section{4 マッチングオイル挿入による改善}

次に，ホール内の間隙へ屈折率が 1.50 のマッチングオイ ルを注入し光結合損失の測定を行った。先にも述べた通り, ノンコーティング光ピンではマッチングオイルを使用する と屈折率差がなくなることで 45 度端面で全反射が起きない ため, メタルコーティング光ピンのみ測定を行っている。

マッチングオイルを使用することにより, 結合損失は送 信・受信ともに0.5 2.0 dB ほどの大幅な改善を確認した。 このことからメタルコーティング光ピンの優位性が確認で きる。

\section{5 解析値と測定値の比較}

マスク径 $200 \mu \mathrm{m}$ の場合について, シミュレーション結果 と実験結果を用いて比較を行った。実験サンプルにおいて は理論的なテーパ角および，円筒断面に凹凸がある形状で， 解析モデルと多少条件は異なるものの, 全体的な傾向を知 るためには有効である。メタルコーティング光ピンの場合, シミュレーション值に比べ, 実験值が最大結合効率で 0.5 1.0 dB ほど結合損失が大きいが, マッチングオイルを 使用することでほぼ同等な結果を得た。これは，シミュ レーション值は理想的な条件で結合効率を算出しているの に対し, 測定值は加工荒れや, 光ピンのあおり, 光導波路 のコアと光ピンの軸ずれなど, さまざまな損失要因が加味 されている。しかし，マッチングオイルを使用することに より，それらの損失要因が和らぎ，理想的な条件に近づい たものと考えられる。

ノンコーティング光ピンでは, 受信の場合に実験值より むシミュレーション值の方が大きな結合損失となっている。 これは, 4.3 節でも少し触れたがホールのテーパ角が影響し ていると考えている。シミュレーションのホールは 72 度の テーパ角を有する光学的な面でとしているが, 実験におい ては，作製したサンプルによって角度は異なりホール端面 の凹凸もある。このため, ホール内の光導波路端面から放 射される光が, 光ピンのミラー部の全反射条件を満たす光 束の割合が大きくなったためと考えられる。
メタルコーティング光ピンでは全反射条件を満たさなく なった光も Au膜により反射するため, ホール内壁の凹凸 の影響がない。また, 光ピンがホール内で傾いていたとも 考えられる。Fig. 14 に光ピンを 5 度傾けたときのシミュレー ション結果を示す。 5 度傾けると受信の結合損失は $6.6 \mathrm{~dB}$ 改善した結果から推測できる。

\section{6 光ピンの回転による影響}

光ピンが円柱形状の光ファイバである場合, 光導波路と の結合においては光ピンが回転し, ミラー面が光ピン内の 光導波路端面と正対しなくなると結合損失が大きくなる。 そこで, 光ピンの回転に対する結合効率の変化を測定した。 実験系は, 先に示したFig. 11 と同じである。用いた光ピン は，コア径 $50 \mu \mathrm{m}$ の GI-MMF の端面を 45 度に加工したもの である。この実験では端面にアルミを蒸着したメタルコー ティング光ピンを用いた。アルミニウム蒸着後に光ピン 45 度面での損失は約 $0.3 \mathrm{~dB}$ であり, $\mathrm{Au}$ とほぼ同等の特性であ る。また, 光導波路側は 4.3 節で使用したマスク径 $200 \mu \mathrm{m}$ のホールのものである。光ピン挿入時の光結合損失が, 送 信・受信いずれも $3.8 \mathrm{~dB}$ 程度となったところを基準として, 光ピンの軸を中心に回転させ, 光結合損失の変化を測定し た。

実験結果を Fig. 15 に示す。グラフより最小結合損失から $1 \mathrm{~dB}$ ダウンするまでの光ピンの回転に対するトレランスは, 送信側が $\pm 8 \mathrm{deg}$ 程度に対して, 受信側は $\pm 13 \mathrm{deg}$ 程度と大 きい。送信側と受信側トレランスの差の原因としては, 送

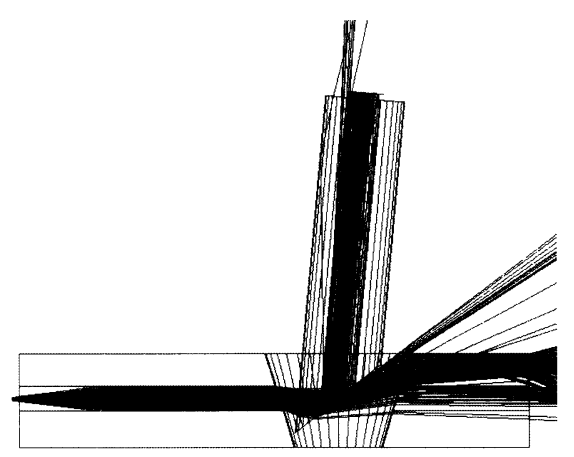

Fig. 14 Calculated results when the non-coating optical pin inclines by 5 -degrees

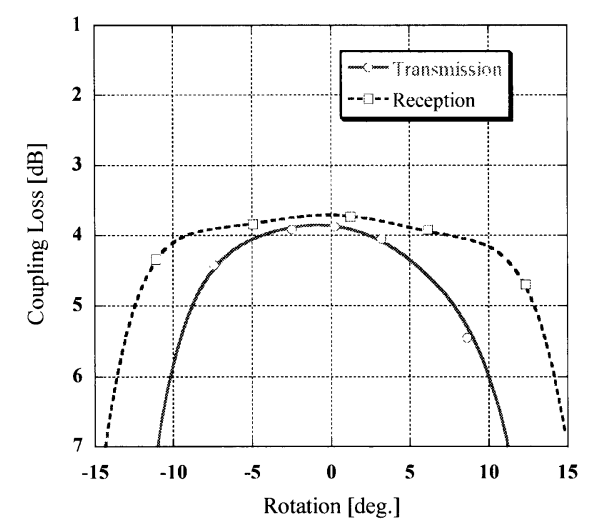

Fig. 15 Coupling loss vs. rotation of optical pin 
信側は光ピン回転によってホール内で光ピンから出射する 光束に角度がつき, 光導波路側の NAを満たさない光が増 えるためと考えられる。

\section{5. 結 論}

光ピンを用いた光SMT の有効性を確認するため, 導波 路上に設けたホールと光ピンとの挿入結合特性を検討した。 光ピン扦入のためのホールを, 光導波路上にレーザアブ レーションを用いて作製した。加工後のホール内の污れは 酸素プラズマアッシングによるクリーニング処理を施すこ とによって, ホールの光学特性は $3 \mathrm{~dB}$ の損失改善を確認し た。しかし，ホール内の凹凹形状が光ピンと光導波路との 結合損失に与える影響が大きいため，ホール内へマッチン グオイルを充てんすることが必要である。このため，45度 ミラー面へメタルコーティングを施した光ピンを作製し, 検討を行った。ホールへのマッチングオイル充てんと, 光 ピンへのメタルコーティングの両者を採用することにより， 結合損失の大幅な改善を得た。回転特性においては導波路 への入射位置ずれの影響で送信側と受信側に差が生じてい るが, $\pm 8 \mathrm{deg}$ 程度の比較的大きなトレランスを得た。これ
らの結果，光ピンの光表面実装技術への適用性が十分高い と考えられる。

謝 辞

本研究の一部は, NEDO プロジェクト「超高密度電子 SI」 の再委託を受けている.

(2003.12.22-受理)

\section{文献}

1）三上 修, 内田禎二: “光表面実装技術の進展”, 電子情報 通信学会論文誌C, Vol. F84-C, No. 9, pp. 715-726, 2001

2) T. Uchida and O. Mikami: "Optical surface mount technology", IEICE Trans. on Electron, E-80-C, pp. 81-87, 1997

3) 佐藤隆志, 伊藤裕一, 小川義雄, 三上 修, 内田禎二, 赤澤 優：“光SMT 向けマイクロミラー付きピンによる 90 度光路変換”, Optics Japan 99, 23pB18, 1999

4) 村田佳一, 宮里健太郎, 渡邊則利, 三上 修, 市村 顕, 平松星紀：“面発光レーザと 45 度ミラー付きファイバとの 光結合”, 電子情報通信学会技術報告, Vol. 102, No. 188, pp. $15-18,2002$ 